\title{
Selective Alterations of Opiate Receptor Subtypes in Monosodium Glutamate-Treated Rats
}

\author{
Elizabeth Young, *John Olney, and Huda Akil \\ Mental Health Research Institute, University of Michigan, Ann Arbor, Michigan, and *Department of Psychiatry, \\ Washington University, St. Louis, Missouri, U.S.A.
}

\begin{abstract}
Neonatal treatment of rats with monosodium glutamate (MSG) has been demonstrated to destroy cell bodies of neurons in the arcuate nucleus including the brain beta-endorphin (B-END) system. The effects on opiate receptors of the loss of B-END is unknown. Neonatal rats were treated with MSG as previously described. After reaching maturity (7-9 months), MSG-treated rats and litter-matched untreated control rats were decapitated and brains dissected into brain regions. Opiate receptor assays were run with $\left[{ }^{3} \mathrm{H}\right]$ morphine (mu receptor ligand) and $\left[{ }^{3} \mathrm{H}\right] \mathrm{D}$-alanine ${ }^{2}-\mathrm{D}$-leucine ${ }^{5}$ (DADL) enkephalin (delta receptor ligand) for each brain region for both MSG and control rats simultaneously. Scatchard plot analyses showed a selective increase in delta receptors in the thalamus only. No corresponding change in mu receptors in the thalamus was found. The cross-competition $\mathrm{IC}_{50}$ data supported this conclusion, showing a loss in the potency
\end{abstract}

of morphine in displacing $\left[{ }^{3} \mathrm{H}\right] \mathrm{DADL}$ enkephalin in the thalamus of MSG-treated rats. This shift in delta receptors produced an $\mathrm{IC}_{50}$ displacement pattern in thalamus, ordinarily a mu-rich area, similar to that of striatum or cortex, delta-rich areas, again indicating an increase in delta receptors. Similar changes in delta receptors in other brain regions were not found. These results represent one of the few examples of a selective and localized shift in delta with no change in mu sites. Furthermore, the delta increase may reflect an up-regulation of the receptors in thalamus after chronic loss of the endogenous opioid B-END. Key Words: Multiple opiate receptors-Monosodium glutamate-Beta-endorphin-Opiate peptides. Young E. et al. Selective alterations of opiate receptor subtypes in monosodium glutamate-treated rats. $J$. Neurochem. 40, 1558-1564 (1983).
Injection of monosodium glutamate (MSG) during the neonatal period produces destruction of cell bodies in the arcuate nucleus of the hypothalamus (Olney, 1969). Dopamine and acetylcholine transferase levels are reduced in the arcuate nucleus after MSG treatment (Lechan et al., 1977; Nemeroff et al., 1977). Since the cell bodies of the brain betaendorphin (B-END) system, which also contains adrenocorticotropic hormone (ACTH), are located within the arcuate nucleus (Watson et al., 1977; $1978 a, b)$, one might expect a decrease in B-END in MSG-treated animals. Immunocytochemical techniques demonstrate a loss of the cell bodies and degeneration of the fibers from the ACTH/B-END system in brain after MSG treatment (Bodnar et al., 1980). This destruction of the ACTH/B-END system has been confirmed by radioimmunoassay
(RIA) measurements of ACTH and B-END in the brain (Kreiger et al., 1979). MSG lesions have no effect on pituitary ACTH or B-END content (Bodnar et al., 1980).

B-END binds to opiate receptors with good affinity; whether it has its own unique subset of opiate receptors in brain remains to be determined (Law et al., 1979; Schulz et al., 1979; Akil et al., 1980). The destruction of the B-END fibers of the arcuate nucleus might be expected to have an effect on opiate receptors in the terminal regions of these arcuate fibers primarily in limbic structures.

The existence of subtypes of opiate receptors was first postulated by Martin et al. (1976) on the basis of pharmacological and behavioral studies. The mu and delta subtypes seem to be the most easily demonstrable in brain tissue preparation and binding
Received June 30, 1982; accepted November 30, 1982

Address correspondence and reprint requests to Elizabeth Young, Mental Health Research Institute, University of Michigan, Ann Arbor, MI 48109, U.S.A.

Abbreviations used: ACTH, Adrenocorticotropic hormone;
a-MSH, Alpha-melanotropin stimulating hormone; B-END, Beta-endorphin; DADL, D-Alanine ${ }^{2}$ D-leucine ${ }^{5}$; DMSO, Dimethylsulfoxide; MSG, Monosodium glutamate; RIA, Radioimmunoassay. 
studies (Lord et al., 1977; Chang and Cuatrecasas, 1979). The mu or alkaloid receptor preferentially binds morphine. The delta or peptide receptor preferentially binds enkephalins and is believed to be the receptor for methionine- and leucine-enkephalin. B-END binds well to both mu and delta receptors in in vitro binding preparations with a slight preference toward the mu sites. Whether B-END binds to mu or delta receptors or neither in vivo is unclear.

There are a number of reasons to investigate the effect of various treatments on different opiate receptor subtypes, particularly in specific brain sites. Although many biochemical studies support the existence of multiple types in brain, little is known about the physiological significance of these subtypes or their unique perturbations by biological events. Furthermore, studies searching for changes in opiate receptors during such treatment as chronic opiate administration have been disappointing. Possibly, this is due to the fact that they measure multiple types of receptors in whole brain. Finally, the MSG model has been proposed as a good tool for depleting B-END in brain, leaving other endogenous opioids unaltered. Uncovering the specific changes in opiate binding accompanying this lesion should help further define the model and evaluate its usefulness for behavioral studies.

One approach in investigating possible changes in opiate receptor subtypes is to look for regional differences. Chang and Cuatrecasas (1979), using low concentrations of radiolabelled dihydromorphine and D-alanine ${ }^{2}$ D-leucine ${ }^{5}$ (DADL) enkephalin, reported differences in the distribution of mu and delta receptors among brain regions. In addition to the traditional Scatchard plot analyses for $\mathrm{mu}$ and delta receptor number in each brain region, we have utilized cross-competition experiments between ligands to study $\mathrm{IC}_{50}$ values. In a sense, the various regions provide "multiple parallel assays" for comparing populations of receptors. A useful index to regional differences is the ratio of $\mathrm{IC}_{50}$ values for a given brain area. Thus,
$\frac{\mathrm{IC}_{50} \text { of morphine vs. }\left[{ }^{3} \mathrm{H}\right] \mathrm{DADL} \text { enkephalin }}{\mathrm{IC}_{50} \text { of morphine vs. }\left[{ }^{3} \mathrm{H}\right] \text { morphine }}$

varies dramatically across regions. In areas containing almost pure mu receptors (i.e., $\left[{ }^{3} \mathrm{H}\right] \mathrm{DADL}$ enkephalin is actually labeling mu sites), the ratio approaches 1 . Conversely, in areas extremely rich in delta, [ $\left.{ }^{3} \mathrm{H}\right] \mathrm{DADL}$ enkephalin labels the latter sites and morphine is impotent against it, leading to high $\mathrm{IC}_{50}$ values in the numerators, and ratios of 10-100.

A final advantage of this approach is that it controls for nonspecific effects, such as differential breakdown in different areas. In the above paradigms of cross-competition, each brain area serves as its own control. This is particularly valuable when different groups of animals are being compared.

\section{MATERIALS AND METHODS}

Neonatal rats were treated with MSG according to a modified schedule of that previously described (Olney, 1969). Two different strains of rats were used. Holtzman rats were obtained from Madison, WI, and treated with $2 \mathrm{~g} \mathrm{MSG} / \mathrm{kg}$ weight on the first 2 postnatal days. Repeat treatment at $4 \mathrm{~g} \mathrm{MSG/kg}$ was done 4,6 , and 8 days postnatally. Male MSG-treated rats and age- and sex-matched controls were killed at approximately 9 months of age. The second group of MSG-treated rats were Harlan rats from Indianapolis, IN, which received the same dose schedule treatment. Female MSG-lesioned rats and ageand sex-matched controls were decapitated at approximately 7 months of age. After decapitation the brains were rapidly removed and dissected on ice into the following brain regions: hypothalamus, hippocampus, striatum, frontal cortex, thalamus, and midbrain. The hypothalami were frozen for subsequent RIA measurement of B-END. Tissue samples from all animals of the same group were pooled for homogenization and subsequent opiate receptor assays. Some animals were perfused and their brains removed for immunohistochemical verification of the destruction of B-END cell bodies.

Opiate receptor binding assays were done on each brain region of MSG-lesioned and control animals simultaneously with both $\left[{ }^{3} \mathrm{H}\right]$ morphine (Amersham) and

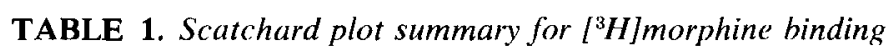

\begin{tabular}{|c|c|c|c|c|c|c|}
\hline & \multicolumn{2}{|c|}{$\begin{array}{c}K_{\mathrm{D}} \\
(\mathrm{n} M)\end{array}$} & \multicolumn{2}{|c|}{$\begin{array}{c}B_{\max } \\
(\mathrm{p} M)\end{array}$} & \multicolumn{2}{|c|}{$\mathbf{r}^{a}$} \\
\hline & Control & MSG & Control & MSG & Control & MSG \\
\hline Striatum & 1.2 & 0.9 & 240 & $267^{b}$ & 0.96 & 0.96 \\
\hline Midbrain & 2.3 & 2.6 & 242 & 257 & 0.97 & 0.99 \\
\hline Cortex & 1.4 & 1.7 & 162 & 182 & 0.98 & 0.95 \\
\hline Hippocampus & 1.3 & 1.1 & 114 & 101 & 0.97 & 0.95 \\
\hline Thalamus 1 & 0.5 & 0.8 & 51 & 53 & 0.87 & 0.95 \\
\hline Thalamus 2 & 1.2 & 1.8 & 102 & 99 & 0.73 & 0.83 \\
\hline
\end{tabular}

${ }^{a}$ Correlation coefficient of the regression line by computer analysis.

${ }^{\circ} \mathrm{p}<0.05$ by multiple linear regression analysis. 
TABLE 2. Scatchard plot summary for $\left[{ }^{3} H\right] D A D L$ enkephalin binding

\begin{tabular}{|c|c|c|c|c|c|c|}
\hline & \multicolumn{2}{|c|}{$\begin{array}{c}K_{\mathrm{D}} \\
(\mathrm{n} M)\end{array}$} & \multicolumn{2}{|c|}{$\begin{array}{l}B_{\max } \\
(\mathrm{pM})\end{array}$} & \multicolumn{2}{|c|}{$r$} \\
\hline & Control & MSG & Control & MSG & Control & MSG \\
\hline Striatum & 6.7 & 4.2 & 500 & 408 & 0.99 & 0.95 \\
\hline Midbrain & 14.3 & 14.2 & 421 & 431 & 0.99 & 0.99 \\
\hline Cortex & 4.3 & 6.7 & 317 & 459 & 0.90 & 0.97 \\
\hline Hippocampus & 7.5 & 7.4 & 294 & 265 & 0.97 & 0.94 \\
\hline Thalamus 1 & 9.9 & 8.8 & 135 & $227^{a}$ & 0.95 & 0.97 \\
\hline Thalamus 2 & 2.7 & 1.7 & 39 & 82 & 0.80 & 0.80 \\
\hline
\end{tabular}

${ }^{a} \mathbf{p}<0.05$ by multiple linear regression analysis.

$\left[{ }^{3} \mathrm{H}\right] \mathrm{DADL}$ enkephalin (Amersham). The assays were performed using a modification of opiate receptor binding assay of Akil et al. Each group contained seven animals. The tissues were homogenized at a concentration of $50 \mathrm{mg} / \mathrm{ml}$ in $0.05 M$ Tris-HCl buffer, $\mathrm{pH} \mathrm{7.4,} \mathrm{(at} 25^{\circ} \mathrm{C}$ ) with $5 \%$ dimethylsulfoxide (DMSO) to minimize freezing effects. Previous studies in our laboratory have demonstrated no differential changes in either $K_{\mathrm{D}}$ or $B_{\max }$ of $\mathrm{mu}$, delta, or kappa receptors induced by DMSO or freezing. In addition, both MSG and control brain tissues were treated identically in this procedure. The brain homogenates were frozen at $-70^{\circ} \mathrm{C}$ until use. Frozen homogenates were placed directly into a $37^{\circ} \mathrm{C}$ water bath and incubated for $45 \mathrm{~min}$ to promote dissociation of any endogenous ligands from the receptors. The tissues were centrifuged at $30,000 \times g$ for $20 \mathrm{~min}$, then resuspended in cold $0.05 \mathrm{M}$ Tris buffer at a concentration of $50 \mathrm{mg}$ tissue/ml buffer. This procedure removes the DMSO added prior to freezing. Aliquots of tissue $(0.3 \mathrm{ml})$ were incubated with $\left[{ }^{3} \mathrm{H}\right] \mathrm{DADL}$ and $\left[{ }^{3} \mathrm{H}\right]$ morphine at concentrations ranging from 0.5 to $25 \mathrm{n} M$ in a total assay volume of $0.5 \mathrm{ml}$. All concentrations were run in triplicate. One mi-

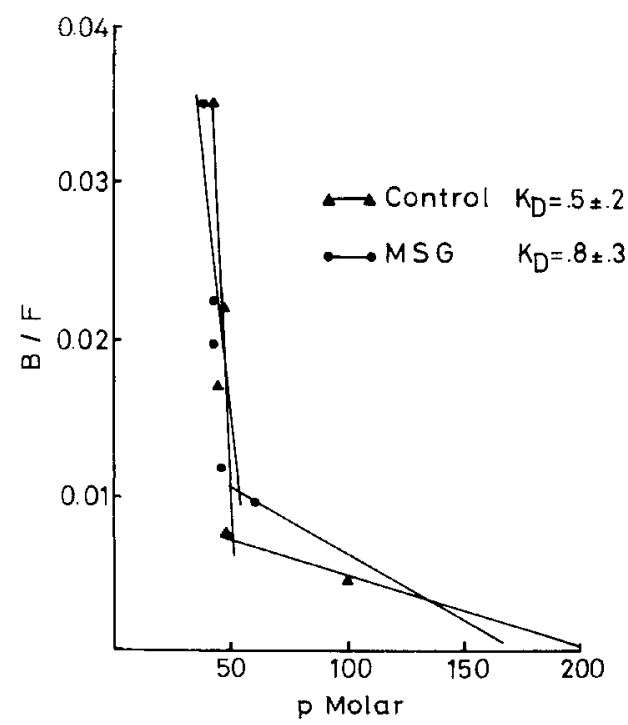

FIG. 1. Scatchard plot for $\left[{ }^{3} \mathrm{H}\right]$ morphine in the thalamus. Control rats: $K_{\mathrm{D}}=0.5 \pm 0.25 ; B_{\max }=51 \pm 22$; MSG rats: $K_{\mathrm{D}}=$ $0.8 \pm 0.3 ; B_{\max }=53 \pm 16 . \mathrm{B} / \mathrm{F}$, bound $/$ free. cromolar morphine and $1 \mu M$ DADL enkephalin were used to define nonspecific binding for $\left[{ }^{3} \mathrm{H}\right]$ morphine and $\left[{ }^{3} \mathrm{H}\right]$ DADL enkephalin, respectively. A mixture of ${ }^{3} \mathrm{H}$-ligand and unlabeled ligand was used to calculate bound and free concentrations at higher concentrations of morphine and DADL enkephalin. In addition, samples were incubated with varying unlabeled concentrations of morphine with $\left[{ }^{3} \mathrm{H}\right] \mathrm{DADL}$ enkephalin and DADL enkephalin with $\left[{ }^{3} \mathrm{H}\right]$ morphine to determine $\mathrm{IC}_{50}$ for both ligands against both ${ }^{3} \mathrm{H}$-ligands. Samples were incubated at $4^{\circ} \mathrm{C}$ for $2 \mathrm{~h}$.

After incubation, samples were rapidly filtered under vacuum using Whatman GF/B glass fiber filters. The filters were washed twice with $4.5 \mathrm{ml}$ of cold Tris buffer and dispersed by shaking in $10 \mathrm{ml}$ of Beckman aqueous scintillation cocktail and counted in a Beckman LS9000 liquid scintillation counter. Aliquots of the crude membrane preparation were assayed using the Biorad protein assays to ascertain that any differences between MSG and control were not due to any dilutional error or differences in

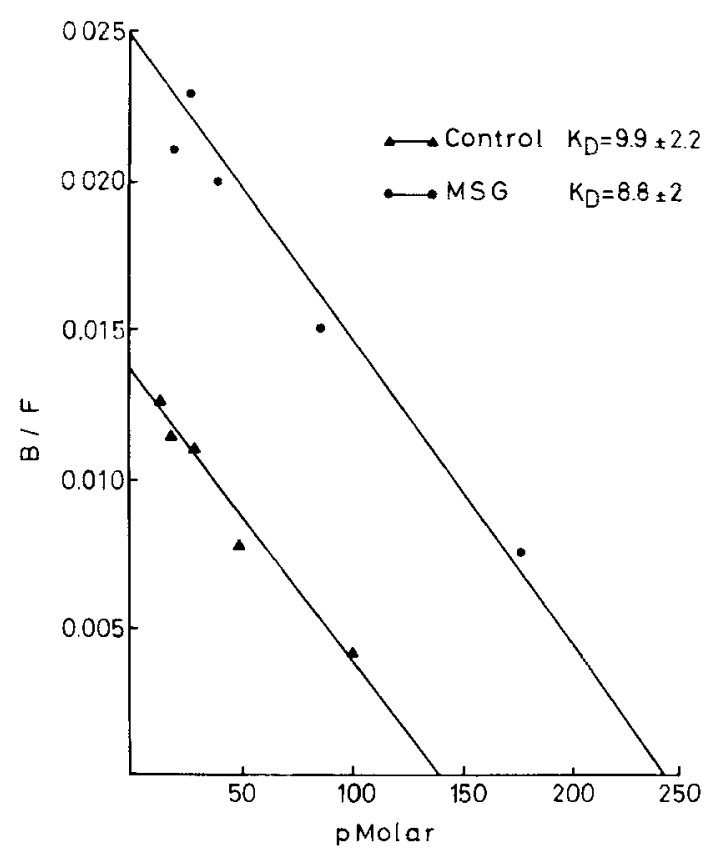

FIG. 2. Scatchard plot for $\left[{ }^{3} H\right] D A D L$ enkephalin in thalamus. Control rats: $K_{\mathrm{D}}=9.9 \pm 2.2, B_{\max }=135 \pm 34$; MSG rats: $K_{\mathrm{D}}=$ $8.8 \pm 2.0, B_{\max }=227 \pm 59 . \mathrm{B} / \mathrm{F}$, bound $/$ free. 


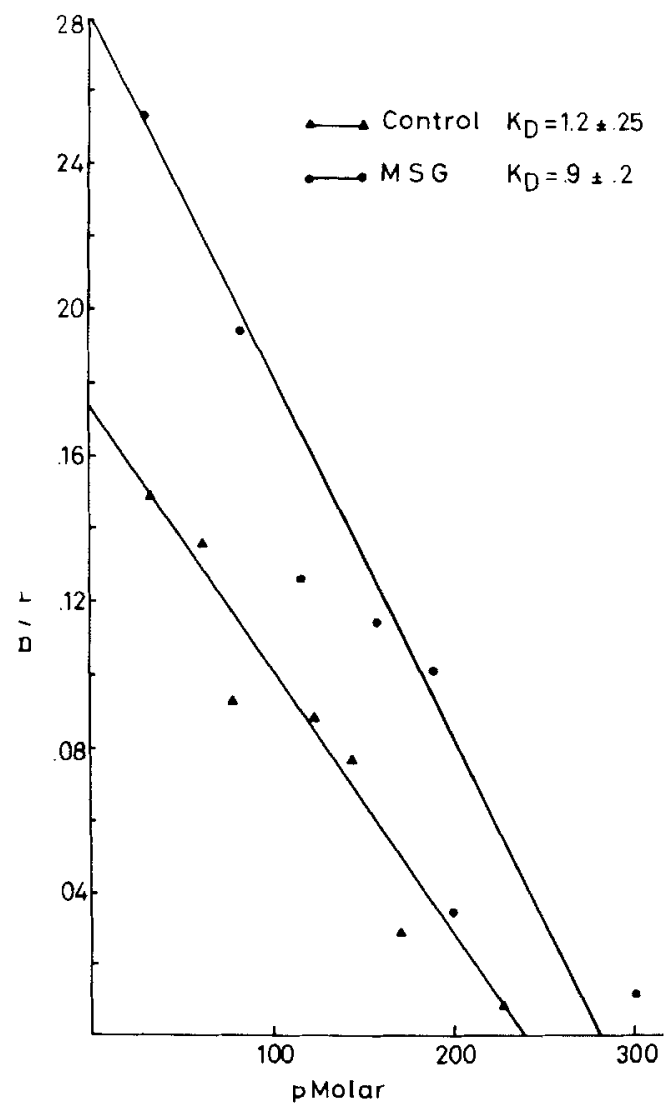

FIG. 3. Scatchard plot for $\left[{ }^{3} \mathrm{H}\right]$ morphine in striatum. Control rats: $K_{\mathrm{D}}=1.2 \pm 0.25, B_{\max }=240 \pm 44 ;$ MSG rats: $K_{\mathrm{D}}=0.9 \pm$ $0.2, B_{\max }=267 \pm 54 . \mathrm{B} / \mathrm{F}$, bound/free.

protein concentrations between groups subsequent to MSG treatment. A given brain region was completely studied in one experiment, simultaneously, to generate the data for comparison of MSG and controls in the Scatchard analyses and the cross-competition paradigms.

Dissociation constants $\left(K_{\mathrm{D}}\right)$ and receptor concentration $\left(B_{\max }\right)$ were obtained from Scatchard plot analysis of the data for each ligand in each brain region using computer generated multiple linear regression analysis.

\section{RESULTS}

Immunohistochemical verification of selected MSG-lesioned versus control animals showed a consistent loss of B-END, immunolabeled in the arcuate of MSG-treated animals as compared with the matched controls. Biochemical measuring of BEND and alpha-melanotropin stimulating hormone (a-MSH) immunoreactivity in the hypothalamus of the MSG and controls showed $>70 \%$ depletion of immunoreactivity of both a-MSH and B-END in MSG versus controls (Akil et al., in preparation). The binding results are summarized in Tables 1-4. The Scatchard plot data for morphine and DADL enkephalin from the first group of animals (Tables 1 and 2) shows little if any change in the $K_{\mathrm{D}}$ between

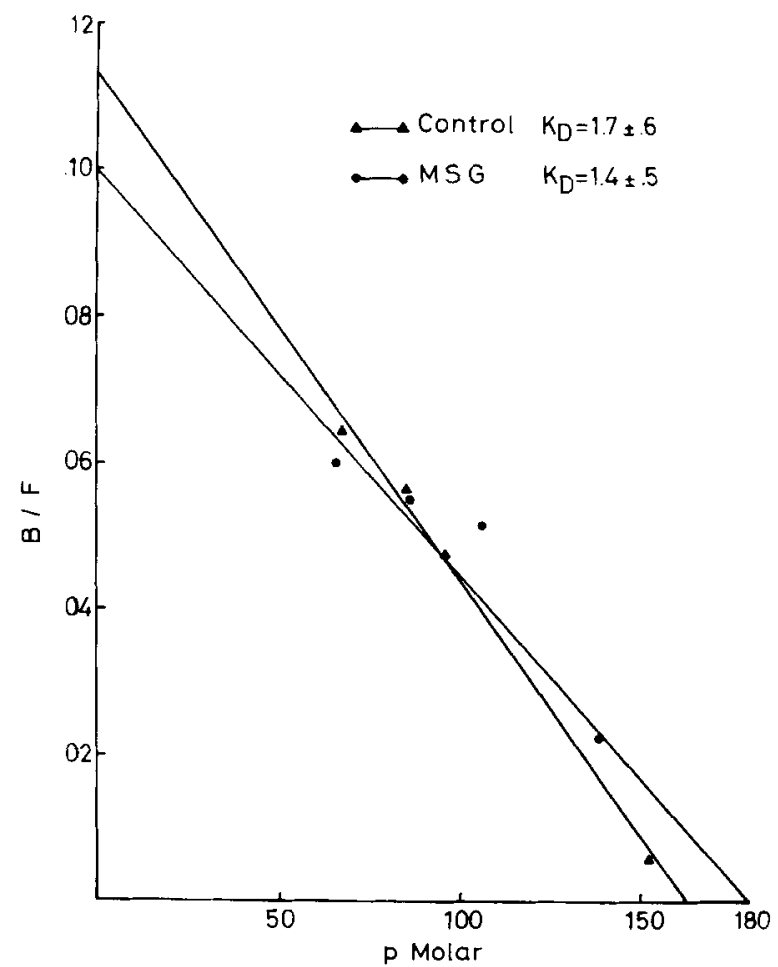

FIG. 4. Scatchard plot for $\left[{ }^{3} \mathrm{H}\right]$ morphine in cortex. Control rats: $K_{\mathrm{D}}=1.4 \pm 0.5, B_{\max }=162 \pm 58$; MSG rats: $K_{\mathrm{D}}=1.7 \pm$ $0.6, B_{\max }=182 \pm 65 . \mathrm{B} / \mathrm{F}$, bound/free.

MSG-treated and control groups. However, there are changes in the $B_{\max }$ in two brain regions, the thalamus and striatum (Figs. 1-3). In the case of the striatum, the increase in mu receptors is not accompanied by any changes in delta receptors. Owing to

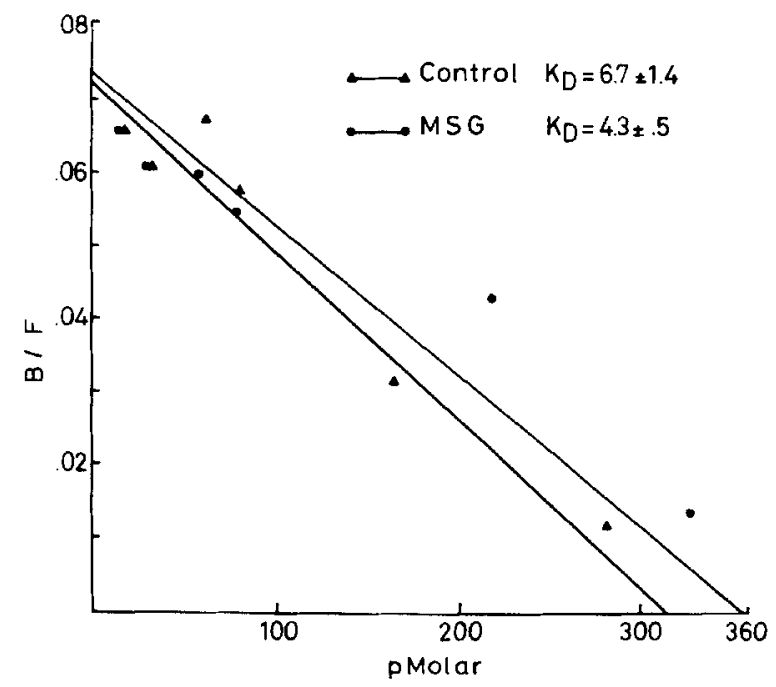

FIG. 5. Scatchard plot for $\left[{ }^{3} \mathrm{H}\right] \mathrm{DADL}$ enkephalin in cortex. Control rats: $K_{D}=4.3 \pm 0.5, B_{\max }=317 \pm 64 ; M S G$ rats: $K_{D}=$ $6.7 \pm 1.4, B_{\max }=459 \pm 93$. 
TABLE 3. Thalamus $I C_{50}(n \mathrm{M})$ in cross-competition

\begin{tabular}{|c|c|c|c|c|c|c|}
\hline & \multicolumn{2}{|c|}{$\left[{ }^{3} \mathrm{H}\right]$ Morphine } & \multicolumn{2}{|c|}{$\left[{ }^{3} \mathrm{H}\right] \mathrm{DADL}$ enkepalin } & \multicolumn{2}{|c|}{$\frac{\mathrm{IC}_{50} \text { vs. }\left[{ }^{3} \mathrm{H}\right] \mathrm{DADL} \text { enk }}{\mathrm{IC}_{50} \text { vs. }\left[{ }^{3} \mathrm{H}\right] \text { morphine }}$} \\
\hline & Control & MSG & Control & MSG & Control & MSG \\
\hline Morphine & $\begin{array}{ll}\text { (a) } 1.1 \\
\text { (b) } 1.5\end{array}$ & $\begin{array}{l}1.5 \\
2.2\end{array}$ & $\begin{array}{l}2.9 \\
2.2\end{array}$ & $\begin{array}{l}54 \\
15\end{array}$ & 1.6 & 19 \\
\hline $\begin{array}{l}\text { DADL } \\
\text { enkephalin }\end{array}$ & $\begin{array}{l}\text { (a) } 24 \\
\text { (b) } 32\end{array}$ & $\begin{array}{l}37 \\
28\end{array}$ & $\begin{array}{l}18 \\
13\end{array}$ & $\begin{array}{l}15 \\
25\end{array}$ & 0.57 & 0.69 \\
\hline
\end{tabular}

(a), experiment 1 ; (b), experiment 2 .

the limited amount of striatal tissue available, we were unable to replicate this study or employ the cross-competition paradigm described above. Thus, this may represent a random chance occurrence or it may be a real change. In the case of the thalamus, the number of delta receptors increased in the MSG-lesioned rats. This could be seen in the first group of MSG rats ( 9 months old, Thalamus 1 ) displayed in Tables 1 and 2 and was replicated in the 7-month-old MSG rats (Thalamus 2). In contrast, regions such as cortex show no changes in Scatchard plot between MSG-treated and control rats (Figs. 4 and 5). The cross-competition experiments further illustrate this point (Tables 3 and 4). Morphine, which ordinarily is more potent in displacing $\left[{ }^{3} \mathrm{H}\right] \mathrm{DADL}$ than DADL enkephalin, suddenly loses much of its potency (Figs. 6 and 7). Thus the $\mathrm{IC}_{50}$ of morphine changes from 3 to $54 \mathrm{nM}$. Since thalamus is a mu-rich area, this loss of potency demonstrates an increase in delta receptors, so that the pattern of $\mathrm{IC}_{50}$ displacement resembles striatum or cortex (Table 4) (Figs. 7-9) more than it does thalamus. This loss of potency of morphine against DADL enkephalin is shown again in the second set of experiments in which the $\mathrm{IC}_{50}$ of morphine shifted from $2 \mathrm{n} M$ in the control animals to $15 \mathrm{nM}$ in the MSGlesioned animals.

\section{DISCUSSION}

The existence of mu and delta receptors as separate receptor subtypes is still controversial. Recent reports on naloxazone, an irreversible antagonist that blocks the binding of both mu and delta ligands, suggest that mu and delta may not be as clearly separated as previously believed. However, cross-protection studies by Robson and Kosterlitz (1979) and studies on selective inhibition of binding with alcohol by Hiller et al. (1981) support different receptor subtypes. This demonstration of differential regulation of mu and delta receptors by neonatal MSG treatment lends further credence to the existence of subtypes of receptors and to the mu and delta receptor paradigm.

The common ligands utilized in multiple opiate receptor binding paradigms, e.g., morphine or dihydromorphine for mu receptors and DADL enkephalin for delta receptors, are not completely specific. Even at low concentrations, some delta receptors will be labeled by morphine and some mu receptors by DADL enkephalin. The lack of selectivity is affected by the relative number of the opiate receptor subtypes intrinsic to each brain. In the case of deltapoor receptor areas like midbrain, DADL enkephalin will label relatively more mu sites than in a deltarich area like striatum or cortex. This is reflected in the relative $\mathrm{IC}_{50}$ values in these regions. In the thalamus of the control group, the ratio $\left(\mathrm{IC}_{50}\right.$ of morphine vs $\left[{ }^{3} \mathrm{H}\right]$ DADL : $\mathrm{IC}_{50}$ of morphine vs $\left[{ }^{3} \mathrm{H}\right]$ morphine) is 1.8 to 2 , indicating a predominance of $\mathrm{mu}$ receptors. For MSG-treated rats this ratio became $36(54 / 1.5)$ in experiment 1 and $7(15 / 2.2)$ in experiment 2 . This change in index supports the Scatchard

TABLE 4. Cortex $I C_{50}(n \mathrm{M})$ in cross-competition

\begin{tabular}{|c|c|c|c|c|c|c|}
\hline & \multicolumn{2}{|c|}{$\left[{ }^{3} \mathrm{H}\right]$ Morphine } & \multicolumn{2}{|c|}{ [ $\left.{ }^{3} \mathrm{H}\right] \mathrm{DADL}$ enkepalin } & \multicolumn{2}{|c|}{$\begin{array}{l}\mathrm{IC}_{50} \text { vs. }\left[{ }^{3} \mathrm{H}\right] \mathrm{DADL} \text { enk } \\
\mathrm{IC}_{50} \text { vs. }\left[{ }^{3} \mathrm{H}\right] \text { morphine }\end{array}$} \\
\hline & Control & MSG & Control & MSG & Control & MSG \\
\hline Morphine & $\begin{array}{l}\text { (a) } 0.6 \\
\text { (b) } 3.5\end{array}$ & $\begin{array}{l}0.9 \\
3\end{array}$ & $\begin{array}{r}62 \\
125\end{array}$ & $\begin{array}{r}48 \\
125\end{array}$ & 69 & 47 \\
\hline $\begin{array}{l}\text { DADL } \\
\text { enkephalin }\end{array}$ & $\begin{array}{l}\text { (a) } 19 \\
\text { (b) } 20\end{array}$ & $\begin{array}{l}23 \\
28\end{array}$ & $\begin{array}{l}7.0 \\
9.5\end{array}$ & $\begin{array}{l}7.0 \\
5.4\end{array}$ & 0.41 & 0.25 \\
\hline
\end{tabular}

(a), experiment 1; (b), experiment 2. 


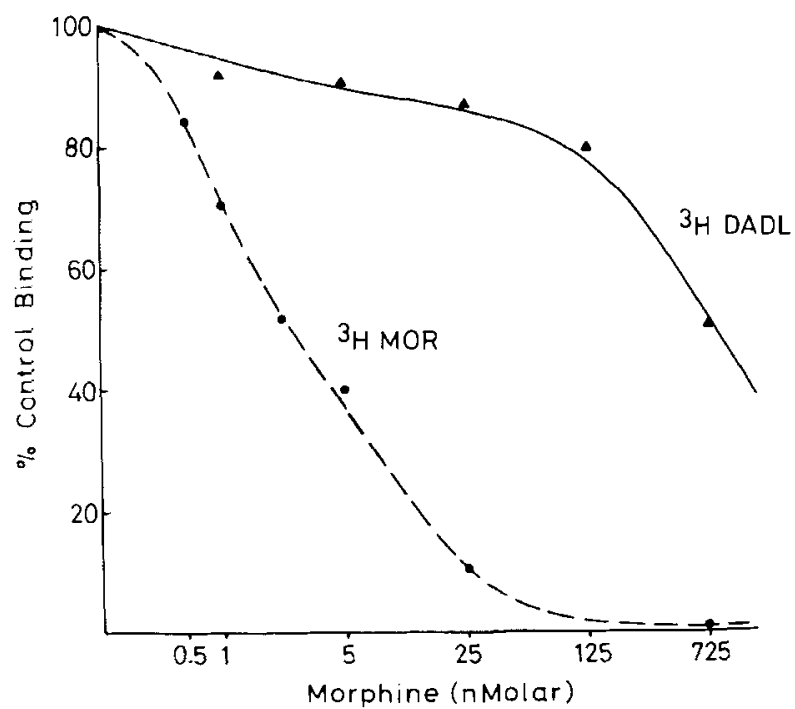

FIG. 6. $I C_{50}$ curve for unlabeled morphine against $\left[{ }^{3} \mathrm{H}\right]$ morphine and $\left.{ }^{3} \mathrm{H}\right] \mathrm{DADL}$ enkephalin in control rats in cortex.

plot data showing a twofold increase in the $B_{\max }$ of DADL enkephalin in the thalamus of MSG-treated rats, with no change in the $B_{\max }$ of morphine binding.

This demonstration of increases in delta receptors in the thalamus is selective among brain regions. Opiate receptor up- or down-regulation has been difficult to demonstrate using receptor binding paradigms despite the clear behavioral changes, such as the development of tolerance to opiates in behavioral paradigms. Previous attempts generally utilized whole brain preparation and one ligand,

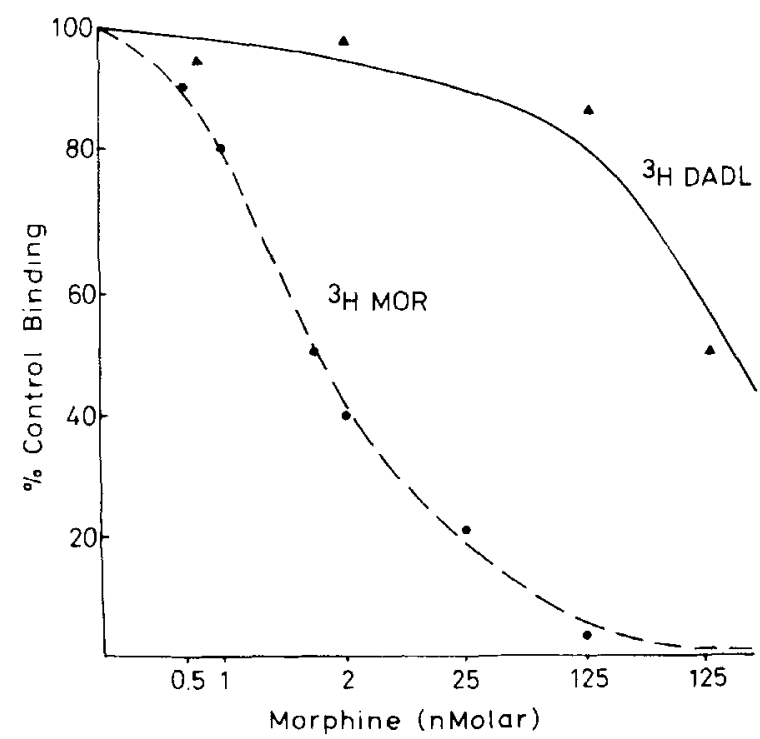

FIG. 7. $\mid \mathrm{C}_{50}$ curve for unlabeled morphine against $\left[{ }^{3} \mathrm{H}\right]$ morphine and $\left[{ }^{3} \mathrm{H}\right] \mathrm{DADL}$ enkephalin in MSG-treated rats in cortex.

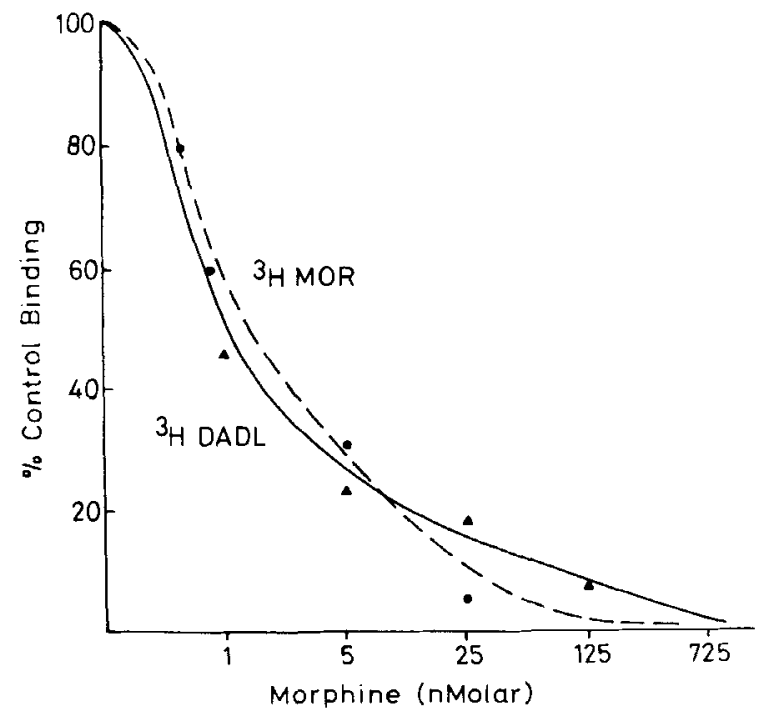

FIG. 8. $I C_{50}$ curve for unlabeled morphine against $\left[{ }^{3} \mathrm{H}\right]$ morphine and $\left[{ }^{3} \mathrm{H}\right] \mathrm{DADL}$ enkephalin in control rats in thalamus.

often a mu receptor agonist such as morphine, dihydromorphine, or etorphine. Few studies have examined brain regions rather than whole brain. This demonstration of selective increase would not have been apparent in a whole brain preparation if only mu receptor ligands were used. The thalamus is a likely area for a receptor change to occur after a MSG lesion, since it is one of the primary terminal regions of the B-END fibers. Whether this binding change leads to a functional or behavioral change in sensitivity to different opiates (e.g., any behavioral

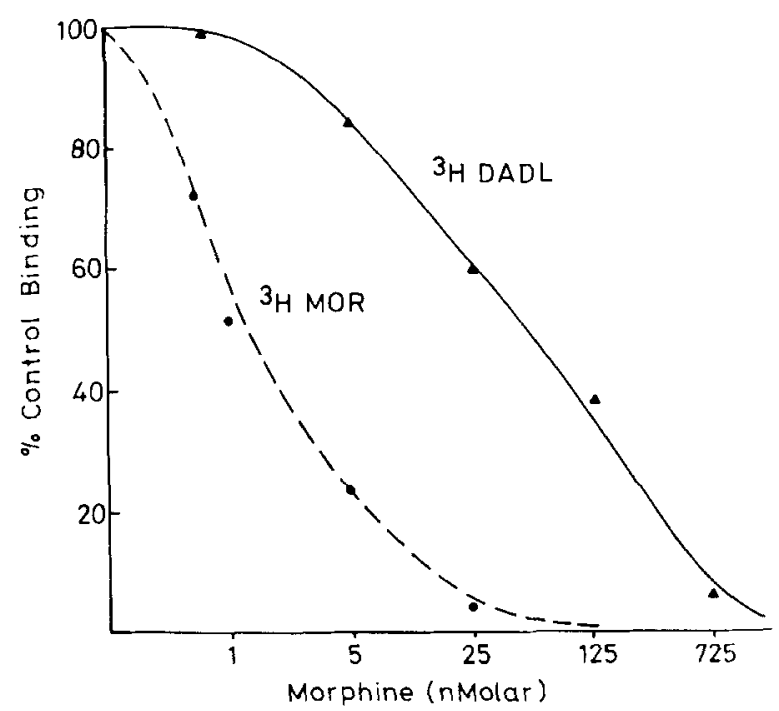

FIG. 9. $\mid \mathrm{C}_{50}$ curve for unlabeled morphine against $\left[{ }^{3} \mathrm{H}\right]$ morphine and $\left[{ }^{3} \mathrm{H}\right] \mathrm{DADL}$ enkephalin in MSG-treated rats in thalamus. Note the similarity of this curve to $\mathrm{IC}_{50}$ curves in cortex a delta receptor-rich area. 
supersensitivity to delta ligands) remains to be determined.

This report of the alteration of one subtype of receptor also has implications for the multiple opiate receptor theory. Although the existence of subtypes was postulated in 1975, the hypothesis has not been entirely accepted. The differential alteration of delta receptors with no changes in mu provides substantial support that these are indeed functionally separable receptors. In the case of the thalamus the alteration in number of one receptor subtype without change in the other receptor implies a separate feedback system. Our data do not address the issue of whether the opiate receptor is a single macromolecule with interconverting forms or distinct macromolecules. What we can conclude, however, is that even if the forms are indeed interconverting, each form can be regulated separately, and an increase in one (e.g., delta in thalamus) is not automatically accompanied by an increase or decrease in the other.

Acknowledgments: This work is supported by NIDA Grant \#DA00259 and RSA MH 38894 (to JO), NIDA Grant \#DA02265 (to HA), and NIMH Grant \#2F32 MH 08085 (to EY).

\section{REFERENCES}

Akil H., Hewlett W. A., Barchas J. D., and Li C. H. (1980) Binding of ${ }^{3} \mathrm{H}$ beta-endorphin to rat brain membrane: A characterization of opiate properties and interaction with ACTH. Eur. J. Pharmacol. 64, 1-8.

Bodnar R. J., Abrams G. M., Zimmerman E. A., Krieger D. T., Nicholson G., and Kizar J. S. (1980) Neonatal monosodium glutamate: Effects upon analgesic responsivity and immunocytochemical ACTH/B-lipotropin. Endocrinology 30, 280284.

Chang K. J. and Cuatrecasas P. (1979) Multiple opiate receptors: Enkephalins and morphine bind to receptors of different specificity. J. Biol. Chem. 254, 2610-2618.

Hiller J. M., Angel L. M., and Simon E. J. (1981) Multiple opiate receptors: Alcohol selectively inhibits binding to delta receptors. Science 214, 468-469.
Krieger D. T., Liotta A. S., Nicholsen G., and Kizer J. S. (1979) Brain ACTH and endorphin reduced in rats with monosodium glutamate-induced arcuate nuclear lesions. Nature 278, 562-563.

Law P. Y., Loh H. H., and Li C. H. (1979) Properties and localization of beta-endorphin receptor in rat brain. Proc. Natl. Acad. Sci. USA 76, 5455-5459.

Lechan R. M., Halpert L. C., and Jackson I. M. D. (1977) Synthesis of lutenizing hormone releasing factor and thyrotropin releasing factor in glutamate lesioned mice. Nature 264, $463-465$.

Lord J. A. H., Waterfield A. A., Hughes J., and Kosterlitz H. W. (1977) Endogenous opioid peptides: Multiple agonists and receptors. Nature 267, 495-499.

Martin W. R., Eades C. G., Thompson J. A., Huppler R. E., and Gilbert P. E. (1976) The effects of morphine and nalorphine like drugs in the nondependent and morphine-dependent chronic spinal dog. J. Pharmacol. Exp. Ther. 197, 517-532.

Nemeroff C. F., Konkol R. J., Bissette G., Youngblood W. W., Martin J. B., Brayeau P., Rone M. S., Prange A. J., Breese G. R., and Kizer J. S. (1977) Analysis of the disruption in hypothalamic-pituitary regulation in rats treated neonatally with MSG: Evidence for the involvement of tuberoinfundibular cholinergic and dopaminergic systems in neuroendocrine regulation. Endocrinology 101, 613-622.

Nilaver G., Zimmerman E. A., Defendini R., Liotta A. S., Krieger D. T., and Brownstein M. J. (1979) Adrenocorticotropin and beta-lipotropin in the hypothalamus: Localization in the same arcuate neurons by sequential immunocytochemical procedures. J. Cell Biol. 81, 50-58.

Olney J. W. (1969) Brain lesions, obesity and other disturbances in mice treated with monosodium glutamate. Science 164, $719-721$.

Robson L. E. and Kosterlitz H. W. (1979) Specific protection of the binding sites of $\mathrm{D}-\mathrm{Ala}^{2} \mathrm{D}-\mathrm{Leu}^{5}$ enkephalin (delta receptors) and dihydromorphine (mu receptors). Proc. R. Soc. Lond. 205, 425-432.

Schulz R., Faase E., Wuster M., and Herz A. (1979) Selective receptors for beta-endorphin on the rat vas deferens. Life Sci. 24, 843-850.

Watson S. J., Barchas J. D., and Li C. H. (1977) Beta-lipotropin: Localization of cells and axons in rat brain by immunocytochemistry. Proc. Natl. Acad. Sci. USA 74, 5155-5158.

Watson S. J., Akil H., Richard C. W., and Barchas J. D. (1978a) Evidence for two separate opiate neural systems. Nature 275, 226-228.

Watson S. J., Richard C. W., and Barchas J. D. (1978b) Adrenocorticotropin in rat brain: Immunocytochemical localization in cells and axons. Science 200, 1180-1182. 